Original Contribution

\title{
SLAUGHTER YIELD AND QUALITY OF MEAT FROM WILD TURKEY (MELEAGRIS GALLOPAVO SILVESTRIS VIEILLOT) REARED IN HUNTING RESERVE IN SOUTH BULGARIA
}

\author{
S. Ribarski ${ }^{1}$, M. Oblakova ${ }^{2^{*}}$ \\ ${ }^{1}$ Trakia University, Stara Zagora, Bulgaria \\ ${ }^{2}$ Agricultural Institute, Hybrid Centre of Poultry Breeding, Stara Zagora, Bulgaria
}

\begin{abstract}
A total of 6 wild turkeys Meleagris gallopavo silvestris Vieillot (3 males, 3 females) at 16 weeks of age were investigated after the species has been imported from Canada in the Hunting reserve of Trankovo, Stara Zagora region. The birds were reared in aviaries and occasionally, let free for hunting tourism. The birds were reared according to conditions adopted in the reserve, fed standard compound feeds according to their category. After 12-hour feed withdrawal, the birds were stunned and slaughtered. The slaughter analysis and meat chemical analysis were conducted at the Meat and meat products unit, Faculty of Agriculture, Trakia University - Stara Zagora. After 24-hour cooling storage at $0-4{ }^{\circ} \mathrm{C}$ the carcasses (without the neck and edible offal) were cut up in commercial parts. Twelve slaughter parameters were determined after evisceration and weighing of internal organs: liver, gizzard, proventriculus, heart, intestines (g). They were used for calculation of slaughter yield. Samples of breast and thigh muscles were collected 24 hours after slaughter and prepared for determination of water, proteins, fat and ash content. Fatty acid composition of triglycerides red and white meat was determined. Triglyceride quantity and quality were assayed by gas chromatography with metal column with Supelcoport 100/200 mesh as stationary phase. The amino acid content was determined by ion-exchange column chromatography. Water holding capacity (WHC, \%) was determined on the $24^{\text {th }} \mathrm{h}$ post slaughter on samples from $m$. Pectoralis superficialis, $m$. Pectoralis profundus and $m$. Femorotibialis. The slaughter analysis showed higher body weight and higher carcass weight in male birds, although the slaughter yield of female was higher than that in males turkeys $67.13 \%$ and $66.87 \%$ respectively ( $>0.05$ ). The differences in protein and fat content of breast and thigh meat in both turkey genders were not significant. The content of the essential amino acid methionine in the breast meat of wild turkeys was $2.61 \mathrm{~g}$ in males and $2.50 \mathrm{~g}$ in females. Lysine concentrations ranged between $9.58 \%$ and $9.69 \%$. The eicosatrienoic omega-3 fatty acids was found only in the meat of male turkeys. Breast meat of female birds did not contain eicosatrienoic and arachidonic fatty acids. There were no differences in the content of macrominerals and trace elements in the meat of both genders wild turkeys.
\end{abstract}

Keys words: turkey, meat composition, water-holding capacity, amino acids, fatty acids

\section{INTRODUCTION}

The turkey (Meleagris gallopavo) is a domestic bird from the Phasianidae family. It originates from North America; it is domesticated in Europe and now is a source of highly dietetic and valuable meat (1). Meat productivity of turkeys is evaluated not only by the live weight, growth performance, feed conversion, but mainly on the basis of its slaughter traits: slaughter yield, weight of edible parts $(2,3)$. The demands for dietetic

\footnotetext{
*Correspondence to: Magdalena Oblakova, Agricultural institute, Hybrid Centre of Poultry Breeding, BG- 6000 Stara Zagora, Bulgaria, moblakova@abv.bg
}

meat with low fat and cholesterol content are continuously increasing as a results of the new healthy nutrition habits. In Mexico (4) Mexican turkeys (Meleagris gallopavo Linnaeus) are used as alternative source of dietetic meat. In experiments with Mexican turkeys (5) male birds attained peak growth at 15.7 weeks of age with weekly weight gain of $259.3 \mathrm{~g}$, whereas the respective values in females were 12.4 weeks of age and 112.0 $\mathrm{g} /$ week.

Many researchers (6-9) demonstrated high slaughter traits in turkeys along with high yield of edible parts. In experiments with broiler turkeys Hristakieva P., (10) reported high 
relative weight of the carcass without offal, head, neck and metatarsus $(70.27 \%-71.95 \%$ in males and $71.92 \%-73.94 \%$ in females). Roberson et al., (6) have investigated three lines of turkeys and established slaughter yield of $75.9 \%$, and breast meat proportion $-28.6 \%$. Having studied the growth performance of BUT-9 turkey broilers, (2) reported average daily weight gain of $140.3 \mathrm{~g}$ in 10 -week-old male birds.

Turley meat is characterised with high protein and mineral content, low fat content and good dietetic and flavour traits. According to the genotype, Hristakieva P., (10) reported meat protein content in turkey broilers from $24.72 \%-25.71 \%$, and fat content within $0.31 \%-0.90 \%$. Benkova et al. (11) found out a high content of high-quality protein in turkey meat (23.06- 23.60\%) which contained the main essential amino acids - lysine, leucine, arginine and valine. It was also rich in potassium, calcium, magnesium, iron and phosphorus. Ribarski, S. et. al (12) also reported protein content up to $26.7 \%$ and fat content up to $0.18 \%$ in breast meat of two different turkey breeds. This makes it a desirable and valuable source of nutrients for those who eat healthy. In the study of López P. E. Et al. (4) the chemical composition of autochthonous Mexican turkeys was similar to that of improved breeds and hybrids. There were statistically significant differences ( $p$ $<0.05$ ) in dry matter content and crude protein in breast muscles, thigh and leg meat with age (7 and 12 months of age) and gender.

The lack of detailed information on wild turkey meat quality was the main incentive of the present study - to investigate and describe some slaughter and meat chemical parameters of Meleagris gallopavo silvestris vieillot farmed in our country.

\section{MATERIAL AND METHOD}

A total of 6 wild turkeys Meleagris gallopavo silvestris Vieillot ( 3 males, 3 females) at 16 weeks of age were investigated after the species has been imported from Canada in the Hunting reserve of Trankovo, Stara Zagora region. The birds were reared in aviaries and occasionally, let free for hunting tourism. The birds were reared according to conditions adopted in the reserve, fed standard compound feeds according to their category.

The slaughter yield and meat chemical analysis were conducted at the Meat and meat products unit, Faculty of Agriculture, Trakia University - Stara Zagora. The birds were weighed before the slaughter (after the 12-hour feed withdrawn. At slaughter, edible offal (liver, heart, and gizzard) were removed after the feet, feathers and heads. After 24-hour cooling at 0$4{ }^{\circ} \mathrm{C}$ the cleaned carcasses without the neck and edible offal, carcasses were cut up in commercial parts. Twelve slaughter parameters were determined after evisceration and weighing of giblets (liver, gizzard, heart), intestines and proventriculus $(\mathrm{g})$. They served for calculation of the slaughter yield.

Samples for physico-chemical analyses of breast and thigh muscles for determination of water, proteins, fat, ash were collected 24 hours after slaughter as per Pojarskaia, L. (13). Fatty acid composition of triglycerides of red and white meat samples was determined after extraction of lipids by the method of Bligh, E. G. and W. J. Dyer (14). Triglycerides were separated by means of thin-layer chromatography on silica gel and mobile phase diethyl ether as per Dimov V., G. and Dimitrov (15). Fatty acids were methylated in $2 \%$ sulfuric acid and anhydrous solution as per Angelov, A. (16). Triglyceride quantity and quality were assayed by gas chromatography with metal column with Supelcoport 100/200 mesh as stationary phase. The amino acid content was determined by ion-exchange column chromatography as per Moore Stanford and William H. Stein (17). Trace elements and macroelements were assayed by atomic absorption spectrophotometry (18).

Water holding capacity (WHC, \%) was determined by the $24^{\text {th }}$ post slaughter on samples from $m$. Pectoralis superficialis, $m$. Pectoralis profundus and m. Femorotibialis. The analysis was performed by the classical method of Graw, W. R. and R. Hamm (19), described by Zahariev Z., Pinkas, A (20) and modified by Petrov J. (21).

The analysis of results was performed by ANOVA, EXCEL 2010. The obtained results were statistically processed and the reliability criteria for the arithmetic mean as obtained by Nikolov G.and Ts. Yablanski (22).

\section{RESULTS AND DISCUSSIONS}

Table 1 presents data from the slaughter analysis of wild turkeys from both genders. Males attained a body weight of $2.18 \mathrm{~kg}$ at 16 weeks of age, and females $-1.70 \mathrm{~kg}(\mathrm{p}<0.001)$. The numerical values of carcass weights were proportional to live weights. Preslaughter and carcass weights of $1.48 \mathrm{~kg}$ and $1.16 \mathrm{~kg}$ in both genders were not compatible to results obtained in fattened hybrids. These values were closer to experiments with Mexican turkeys of Pérez-Lara, M. A (5), where males 
RIBARSKI S., et al.

attained $6 \mathrm{~kg}$ at 40 weeks of age and females $3.6 \mathrm{~kg}$ at 35 weeks of age.

Oblakova (2) reported that the fattened BUT-9 broiler turkey attained slaughter weights of $9666 \mathrm{~g}$ (males) and $7300 \mathrm{~g}$ (females) with respective carcass weight of $7225 \mathrm{~g}$ and $5711 \mathrm{~g}$ and higher slaughter yields in female birds (78.24\%) than in males $(74.74 \%)$ on the 16 week of slaughter. The carcass weights in the different genotypes of broiler turkeys under industrial production systems are various. At 16 weeks of age, weights between $5361.67 \mathrm{~g}$ and $4996.67 \mathrm{~g}$ were reported in different groups (10). In our experiment, females exhibited insignificantly higher slaughter yield (67.13\% vs $66.64 \%$ in males).

Slaughter yield varied within a wide range depending on the animal species and breed and the fattening extent. In turkeys it varies from $85 \%$ to $87 \%$ (23).

The detailed slaughter analysis suggested that aforementioned results were applicable to all carcass cuts. The most specific differences between genders were encountered with respect to the heart, gizzard, intestines and thighs.

Table1. Slaughter analysis of wild male and female turkeys at 16 weeks of age

\begin{tabular}{|l|l|l|}
\hline Parameters $(\mathrm{kg}, \mathrm{g})$ & Female & male \\
\hline 1. Live weight before slaughtering, $\mathrm{kg}$ & $1.70 \pm 0.11$ & $2.18 \pm 0.11 \mathrm{c}$ \\
\hline 2. carcass weight, $\mathrm{kg}$ & $1.16 \pm 0.08$ & $1.48 \pm 0.12$ \\
\hline 3. carcass weight /after $24 \mathrm{~h} / \mathrm{kg}$ & $1.14 \pm 0.79$ & $1.46 \pm 0.11$ \\
\hline 4. \% carcass yield & $67.13 \pm 0.28$ & $66.84 \pm 2.10$ \\
\hline 5. heart, g & $9.37 \pm 0.33$ & $12.93 \pm 0.18 \mathrm{c}$ \\
\hline 6. liver, g & $40.93 \pm 7.77$ & $50.30 \pm 1.43$ \\
\hline 7. proventriculus, g & $4.57 \pm 0.10$ & $6.43 \pm 0.46 \mathrm{~b}$ \\
\hline 8. gizzard (full), g & $49.00 \pm 1.20$ & $65.10 \pm 4.40 \mathrm{a}$ \\
\hline 9. gizzard (empty),g & $35.90 \pm 2.01$ & $48.77 \pm 4.57$ \\
\hline 10.intestines, g & $34.87 \pm 6.47$ & $115.13 \pm 10.55 \mathrm{~b}$ \\
\hline 11. head, g & $51.77 \pm 1.09$ & $64.70 \pm 2.22 \mathrm{a}$ \\
\hline 12. thigh, g & $65.63 \pm 4.34$ & $103.87 \pm 10.03 \mathrm{c}$ \\
\hline
\end{tabular}

Significatly at a $\mathrm{p}<0.05, \mathrm{~b} p<0.01, \mathrm{c} p<0.001$

Table 2 presents the results from the meat chemical analysis of male and female wild turkeys.

Table 2. Chemical composition of turkey meat

\begin{tabular}{|l|l|c|c|c|c|}
\hline & $\mathrm{n}$ & Water \% & Protein\% & Fat\% & Ash\% \\
\hline breast muscles & & & & & \\
Wild Turkey $\widehat{\widehat{O}}$ & 3 & $73.33 \pm 0.23$ & $24.68 \pm 0.22$ & $0.83 \pm 0.06$ & $1.14 \pm 0.01$ \\
Wild Turkey + & 3 & $73.31 \pm 0.21$ & $24.65 \pm 0.35$ & $0.91 \pm 0.14$ & $1.16 \pm 0.01$ \\
\hline Thigh muscles & & & & & \\
Wild Turkey o & 3 & $73.40 \pm 0.35$ & $21.71 \pm 0.24$ & $3.69 \pm 0.60$ & $1.19 \pm 0.04$ \\
Wild Turkey + & 3 & $72.87 \pm 0.11$ & $22.36 \pm 0.34$ & $3.54 \pm 0.45$ & $1.22 \pm 0.03$ \\
\hline
\end{tabular}

The chemical analysis of breast meat showed protein content of $24.68 \%$ in males and $24.65 \%$ in females. There were no differences between both sexes with respect to this parameter. The results differed from data reported by López P. E et al. (4) about higher protein content of breast muscles of wild turkeys in females $-21.8 \%$ vs $18.4 \%$ in males $(p<0.05)$. Other sources reported variable results in breast meat of domestic turkeys from $21.8 \%$ (24), to $32.4 \%$ (25).

The lipid content of breast meat was slightly higher in females. Breast meat of wild turkeys had a low lipid content $(\mathrm{p}<0.001)$, only $0.91-$ $0.83 \%$. In female domestic NCB turkeys, breast meat fat content was $2.87 \%$ (26). Ash content o female breast meat was $1.16 \%$ ( $p>0.05$ vs that of males). The presented data are comparable to the results of Werner, $\mathrm{C}$. (27). In wild turkeys, this parameter was with higher values than those reported by López $\mathrm{P}$. E. (4): $0.64 \%$ in female and $0.84 \%$ in male birds $(p<0.05)$. Gender-related differences in the meat water content were not established.

Thigh meat protein content was higher $22.36 \%$ in female wild turkeys and $21.71 \%$ in 
RIBARSKI S., et al.

male ( $>00.05$ ). López P. F., (28) reported values of $18.4 \%$ (male) and $19.6 \%$ (female). There were no differences in fat and ash contents. These data are in accordance with the reports of Vega Niño, López Pérez Elvia (29). Having studied the physico-chemical properties of skeletal muscles of two groups of turkeys - White Emperor and mini-turkey line, Ribarski, S., (12) reported high protein content in skeletal muscles of both breeds. Fat content was higher in the meat of mini-turkeys.

Water holding capacity of meat reflects its essential properties to bind water and is closely related to quality traits as tenderness, juiciness and colour. The analysis of meat showed that female wild turkeys had higher WHC\% than males: $24.47 \%$ and $20.82 \%$. In general, differences between genders were not found out. WHC\% depends on a number of factors, for example preslaughter feeding - it increased from $25.49 \%$ in fasted to $32.31 \%$ in fed turkeys. Stress also resulted in high WHC\% of turkey meat: it could increase from $26.92 \%$ to $30.82 \%$ (30).

Table 3 presents the total amount of amino acids in the breast meat of wild turkeys from both genders. Meat is a main source of proteins, providing all amino acids essential for human nutrition (31). Also, this meat is an excellent source of minerals, especially iron, zinc, selenium and phosphorus. The values of studied 17 amino acids suggested that among non-essential ones, glycine percentages, important for meat quality, were $4.69 \%$ in males and $4.61 \%$ in females. The gender differences were insignificant. A similar tendency was established with respect to meat proline contents $4.48 \%$ and $4.00 \%(p>0.05)$.

The differences in contents of some essential amino acids associated with the nutritional value of meat (methionine and lysine) were slight $(p>0.05)$. The proportions of lysine, important for muscle development, were $9.58 \%$ in male and $9.69 \%$ in female wild turkeys.

The essential amino acid methionine percentages in the breast meat of wild turkeys were $2.61 \%$ in males and $2.50 \%$ in females, while in Nord Caucas Bronze $1.59 \%$ and $1.70 \%$ respectively (26). The share of lysine in wild male turkeys was $9.58 \%$ and in females$9.69 \%$. The comparison with meat of other species, the average contents of lysine $(1.3 \%)$ and leucine $(1.4 \%)$ in Egyptian geese were lower than values in ostrich meat $(1.8 \%$ and $1.6 \%$ (32).

Table 3. Total amino acids in breast muscles (\%)

\begin{tabular}{|l|c|c|}
\hline amino acids & \multicolumn{2}{|c|}{ wild turkey } \\
\hline serine & $1.75 \pm 0.09$ & $1.67 \pm 0.07$ \\
\hline aspartic acid & $9.12 \pm 0.02$ & $9.25 \pm 0.02$ \\
\hline glutamic acid & $18.31 \pm 0.07$ & $18.33 \pm 0.29$ \\
\hline proline & $4.48 \pm 0.08$ & $4.00 \pm 0.29$ \\
\hline cysteine & $0.86 \pm 0.04$ & $0.72 \pm 0.19$ \\
\hline glycine & $4.69 \pm 0.09$ & $4.61 \pm 0.13$ \\
\hline alanine & $6.02 \pm 0.03$ & $6.04 \pm 0.06$ \\
\hline tyrosine & $2.59 \pm 0.06$ & $2.50 \pm 0.09$ \\
\hline threonine & $3.24 \pm 0.07$ & $3.14 \pm 0.06$ \\
\hline valine & $5.76 \pm 0.02$ & $5.80 \pm 0.04$ \\
\hline methionine & $2.61 \pm 0.05$ & $2.50 \pm 0.05$ \\
\hline isoleucine & $5.39 \pm 0.03$ & $5.40 \pm 0.02$ \\
\hline leucine & $9.20 \pm 0.04$ & $9.27 \pm 0.05$ \\
\hline phenylalanine & $4.32 \pm 0.16$ & $4.60 \pm 0.02$ \\
\hline histidine & $5.72 \pm 0.03$ & $6.03 \pm 0.09$ \\
\hline lysine & $9.58 \pm 0.04$ & $9.69 \pm 0.05$ \\
\hline arginine & $6.32 \pm 0.06$ & $6.41 \pm 0.09$ \\
\hline
\end{tabular}

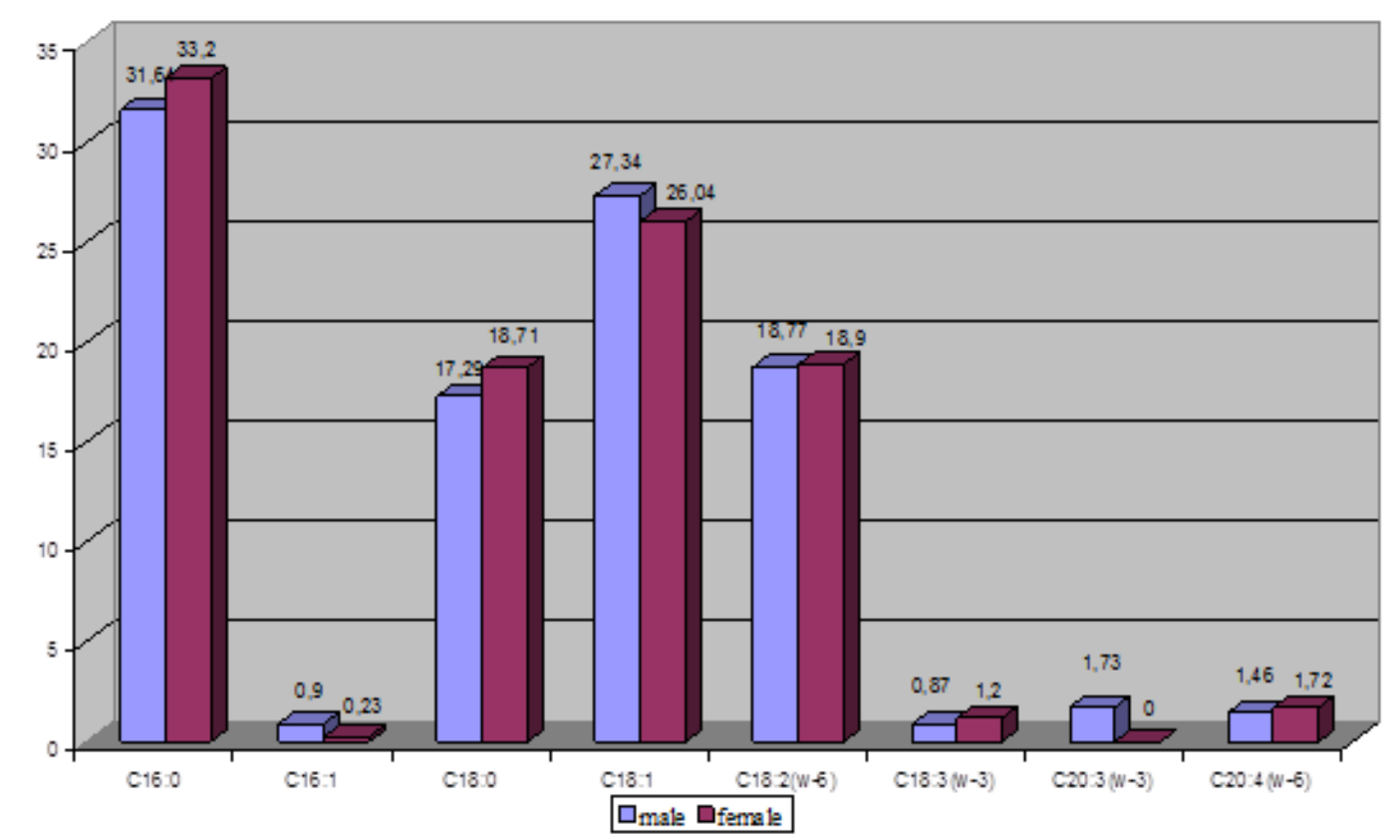

Figure 1. Fatty acid composition in breast muscles \% 
The fatty acid content of triglycerides in the breast meat of wild turkeys is presented on Figure 1. The palmitic (C16:0) and stearic (C18:0) acids had higher values in females $33.20 \%$ and $18.71 \%$ than in males: $31.64 \%$ and $17.29 \%$ respectively. Both acids accounted for $51.91 \%$ of the total fat content of breast meat. In a study on the breast meat of Meleagris gallopavo Linn, (29) reported monounsaturated fatty acid contents of 43.30 and $38.41 \%$, as well as $20.17 \%$ and $24.91 \%$ polyunsaturated fatty acids (PUFA) in two diets for turkeys. In our study, PUFA content was $23.73 \%$ in male and $22.05 \%$ in female. In female wild turkeys, there were no traces of the $\omega-3$ eicosatrienoic acid $\mathrm{C} 20: 3$, while its content in the breast meat of males was $1.73 \%$.
The contents of the monounsaturated oleic acid (C18:1) - 26.04\% in female and $27.34 \%$ in male birds were impressive. According to (4) the breast meat of the local Mexican turkey had higher PUFA content in females than in males $(27.6 \%$ vs $23.8 \%)$.

Numerous authors have studied the effect of various dietary animal and vegetable fats on the fatty acid composition of poultry meat. The lipids in broiler meat could be modified via supplementation of linoleic (LA) and linolenic (LNA) acids, vegetable oils, fish meal $(33,34)$. The amount of PUFA increased when diets were supplemented mainly with long-chain $\omega$ 3 FA [eicosapentaenoic (EPA), docosapentaenoic (DPA) and docosahexaenoic (DHA) fatty acids (35).

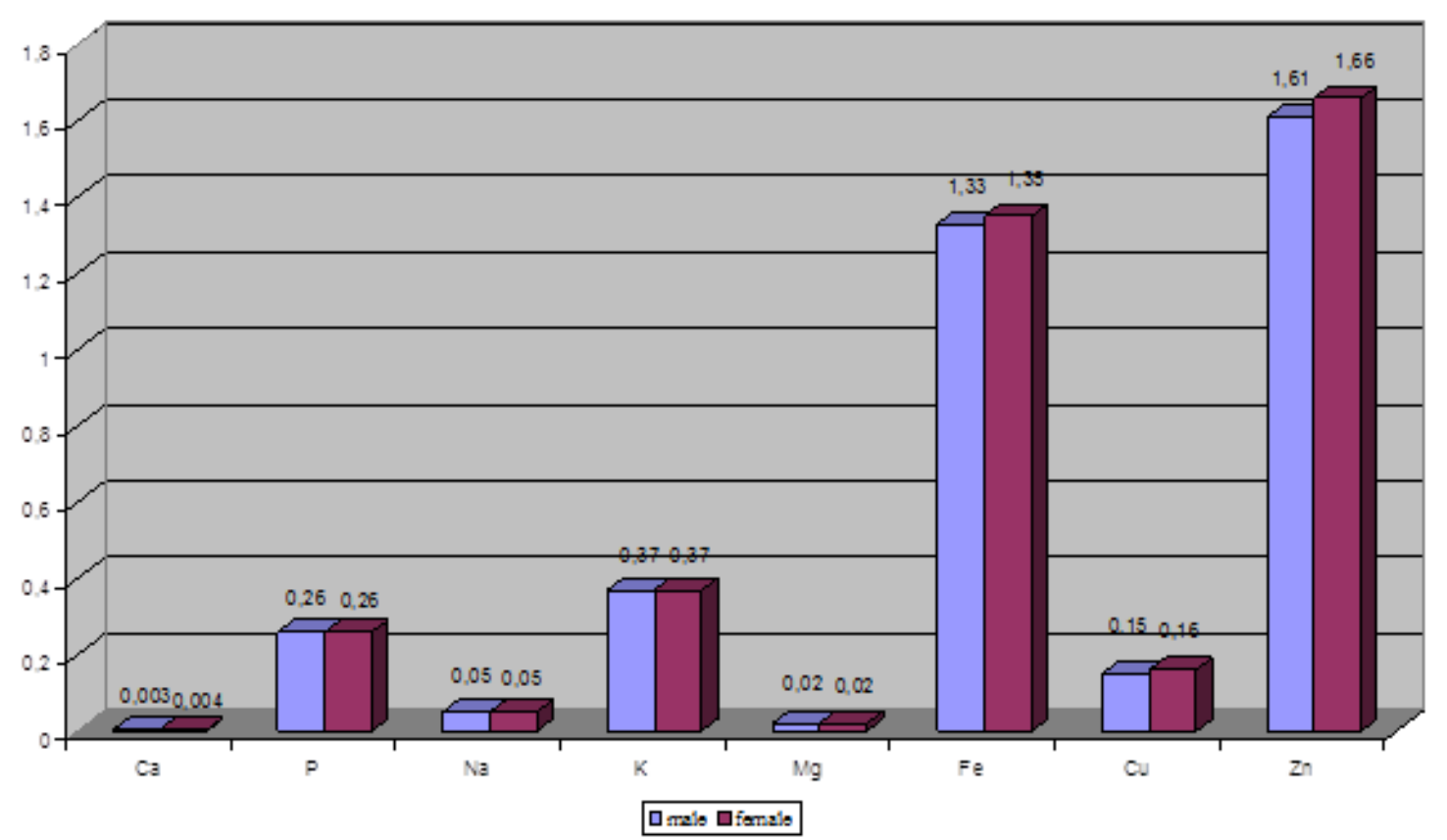

Figure 2. Contens of mineral nutriens in wild turkey breast muscles - \%

The mineral content of breast muscles showed highest contents of $\mathrm{Zn}$ and $\mathrm{Fe}$ in both sexes (Figure 2). The high content of these trace minerals in meat is important for human health. Geldenhuys et al. $(36,37)$ demonstrated that in the meat of Egyptian geese, phosphorus content was the highest, followed by potassium and magnesium, while $\mathrm{Fe}$ was $5.3 \%$. This high $\mathrm{Fe}$ content was associated with metabolic capacity and fibrous structure of breast muscles as explained by. (36). In flying birds, this muscle is composed mainly by type IIa fast-twitch oxidative glycolytic fibres together with small proportion of type IIa fast-twitch glycolytic fibres $(38,39)$. The IIa fibres are aerobic so they have high myoglobin content for supply with oxygen. The $\mathrm{Fe}$ content in Egyptian geese breast meat is comparable to that of the ostrich M. iliofibularis and fat higher than values reported by (40). The average concentrations of $\mathrm{Fe}$ and $\mathrm{Cu}(0.4 \%)$ were also higher than respective values in beef, lamb, pork, poultry and turkey meat (41).

\section{CONCLUSIONS}

On the basis of presented results, the following conclusions on slaughter traits and meat chemical composition in wild turkeys could be made:

1. The slaughter analysis were indicative for higher live weight and clean carcass weight in male birds, although the slaughter yield of female wild turkeys was higher than that in males $67.13 \%$ and $66.87 \%$ respectively ( $\mathrm{p}>0.05)$.

2. The chemical analysis of meat did not demonstrate significant differences in protein 
and fat content of breast and thigh meat between both genders.

3. The content of the essential amino acid methionine in the breast meat of wild turkeys was $2.61 \mathrm{~g}$ in males and $2.50 \mathrm{~g}$ in females. Lysine concentrations in wild turkey meat ranged between $9.58 \%$ and $9.69 \%$.

4. The eicosatrienoic omega-3 fatty acids was found only in the meat of male wild turkeys. Breast meat of female birds did not contain eicosatrienoic and arachidonic fatty acids.

5. There were no differences in the content of macrominerals and trace elements in the meat of both genders wild turkeys.

\section{REFERENSES}

1. Brant, A.W. A brief history of the turkey. World's Poultry Science Journal, 54, 365373, 1998.

2. Oblakova, M. Stady of growth potentials and slaughter analysis of BUT- 9 broiler turkey poults. /Bulgarian Journal of Animal Science, 10:137-142, 2004.

3. Oblakova, M., P.Hristakieva, M.Lalev. Slaughter analysis of poults hatched from eggs of different mass. International science conference, 4-5 june, 1, c. 162-167, 2009.

4. López P. E., Uriostegui R. E. , López P. F. , Pró M. A., Hernández M. O2, Guerrero S. I. Calidad nutricional de pechuga q muslo y pierna de guajolotes natives mexicanos (MELEAGRIS GALLOPAVO L.), 2011.

5. Pérez-Lara, M. A. Camacho-Escobar, J. C. García-López, S. Machorro-Samano, N. Y. Ávila-Serrano, J. Arroyo-Ledezma, Mathematical modeling of the native Mexican turkey's growth, Open Journal of Animal Sciences, Vol.3, No.4, 305-310, 2013

6. Roberson, K. D., A.P. Rahn, R. J. Balander, M. W. Orth,D. M. Smith, B. L. Booren, A. M. Booren, W. N. Osburnand R. M. Fulton, Evaluation of the growth potential, carcass components and meat quality characteristics of three commercial strains of tom turkeys. J. Appl. Poult. Res., 12: 229-236, 2003.

7. Roberson, K. D., J. L. Kalbfliesch, D. Dransfield, Comparison of growth performance and carcass component yeild of a new strain of tom turkeys to other comercial strais. International Journal Poultry Science 3(12):791- 795, 2004,

8. Brake, J., G. B. Havenstein, P.R. Ferket, D.V. Rives and F.G. Giesbrecht, Relationship of sex, strain, and body weights to carcass yield and offal production in turkeys. Poult. Sci., 74: 161168, 1995.

9. Larsen J. E., R. L. Adams, I. C. Peng, W. J. Stadelman. Growth, feed conversion and yields of turkey parts of three strains of hen turkeys as influenced by age. Poultry Science , 65, 11: 2076-81, 1986.

10.Hristakieva P. Opportunities to use lines of turkeys' gene pool of producing hybrid turkey. Thesis, 2006, p. 102

11.Benkova J., J. Lukacka, Chemicke a fyzikalne vlastnosti svalov 16-tyzdnovych moriek Ivagal. Journal-of-Farm-AnimalScience v. 27 p. 123-130. (Slovakia), 1994,

12.Ribarski, S., M. Lalev, M. Oblakova. Phisico-chemical characteristics and micromorphological feature of turkey skeleton musculature, Journal of animal science, 2, 106-109, 2001.

13.Pojarskaia, L. Food industry, 289, 1964.

14.Bligh, E. G. and W. J. Dyer. A rapid method of total lipid extraction and purification. Canadian Journal of Biochemistry and Physiology, 37; 8, 911917, 1959.

15.Dimov V., G. Dimitrov, Analysis of nonesterified fatty acids in blood. Animal Science (Sofia), XV, No 4, 92-98, 1978.

16. Angelov, A. Effect of plant oils adopted by the diet on the content and composition of lipids in tissues at early weaned lambs. Thesis. c. 47-48, 1994.

17.Moore Stanford and William H. Stein, Photometric ninhidrin method for use in the chromatography of amino acids (Prom the Laboratories of The Rockefeller Institute for Medical Research, New York),(Received for publication, June 8, 1948) 367-388. http://www.jbc.org/, 1948.

18.AOAC International, Official Methods of Analysis of AOAC The calculation of the costs for production of lean pork meat International Association of Official Analytical showed that during the starter period, Chemists International, Gaithersburg, MD,USA, 2007.

19.Graw, W. R. and R. Hamm. Muscle as food. In: Food Science and Technology, A Series of Monographs 1985 (Ed. P. J. Bechtel). Academic Press, New York, 1953.

20.Zahariev Z., Pinkas, A. Methodology for conducting experiments mortem analysis and qualitative assessment of the meat, NAPO, Sofia, 1979.

21.Petrov, J., 1982, pecies and breeds ,particularity in micromusclelature skeleton muscle on Postnatal in animal ontogenesis, Thesis.

22.Nikolov G., Ts. Yablanski. Manual for exercises on animal genetic. Zemizdat, Sofia., 134, 1981.

23. Siler R., B. Knize, H. Knizetova. Rust a produktice masa u hospodarskych zvirat, SZN, Praha, 80- 86, 1980. 
24.Asociación de Cunicultores de Chile, (ACUCH). 2003. (en línea). Consultado 10 nov. 2008. Disponible en http://www.sitec.cl/DOC/Mercado\%20naci onal20 de $\% 201 \mathrm{a} \% 20$ carne $\% 20 \mathrm{de} \% 20$ conejo.doc

25.Mountney, G. J. and C. R. Parkhurst. Tecnología de productos avícolas. Ed. ACRIBIA, S. A. Pp. 69-81, 1995.

26.Oblakova M., S. Ribarski, Nikolay Oblakov. Study on slaughter analysis, physico- chemical characteristics and micromorphological features of North Caucasian bronze turkey meat, Science \& Technologies Volume V, Number 5, Animal studies \& Veterinary medicine 7582, 2015.

27.Werner, C., J. Riegel, M. Wicke. Slaughter performance of four different turkey strains, with special focus on the muscle fiber structure and the meat quality of the breast muscle. Poultry Science, 87, 1849-1859, 2008.

28.López, P. F. Calidad nutricional de la carne y características organolépticas de embutidos de guajolote autóctono. Tesis Profesional Departamento de Zootecnia UACH, 59 p. 2009.

29. Vega Niño, López Pérez Elvia, Efecto del aceite esencial de orégano en calidad de la canal de guajolote nativo (Meleagris gallopavo Linn) http://www.chapingo.mx/zootecnia/assets/1 2vega.pdf

30.Ngoka, D. A., G. W. Froning, S. R. Lowry, A. S. Babji. Effects of sex, age, preslaughter factor, and holding conditions on the quality characteristics and chemical composition of turkey breast muscles. Poultry Science, 61, 1996-2003, 1982

31.Pereira P. M., Vicente A. F. Meat nutritional composition and nutritive role in the human diet. Meat Sci. ;93:586-592, 2013.

32.Sales J., Hayes J. P. Proximate, amino acid and mineral composition of ostrich meat. Food Chem. ;56:167-170, 1996.
33.Lopez-Ferrer, S., M. D. Baucells, A. C. Barroeta, and M. A. Grashorn, Influence of vegetable oil sources on quality parameters of broiler meat. Archiv. Geflug. 63:29-35, 1999a.

34.Hulan, H. W., F. G. Proudfoot, and D. M. Nash. The effects of different dietary fat sources on general performance and carcass fatty acid composition of broiler chickens. Poult. Sci. 63:324-332, 1984.

35.Lopez-Ferrer, S., M. D. Baucells,,1 A. C. Barroeta, and M. A. Grashorn, n-3 Enrichment of Chicken Meat. Use of Very Long-Chain Fatty Acids in Chicken Diets and Their Influence on Meat Quality: Fish Oil, Poultry Science 80:741-752, 2001.

36. Geldenhuys G., Hoffman L. C., Muller N. Aspects of the nutritional value of cooked Egyptian goose (Alopochen aegyptiacus) meat, compared to other well-known fowl species. Poult. Sci. ;92:3050-3059, 2013 a.

37. Geldenhuys G., Hoffman L. C., Muller N. The fatty acid, amino acid, and mineral composition of Egyptian goose meat as affected by season, gender, and portion, Poult. Sci. January 13, http://ps.oxfordjournals.org/content/early/2 015/03/25/ps.pev083.full, 2015

38.Butler P. J.Exercise in birds. J. Exp. Biol. 160:233-262,1991.

39.Baeza E., Chartrin P., Meteau K., Bordeau T., Juin H., LeBihanDuval E., Lessire M., Berri C. Effect of sex and genotype on carcass composition and nutritional characteristics of chicken meat. Br. Poult. Sci. ;51:344-353, 2010.

40.Brand M. M. 2006. MSc Thesis. Univ. Stellenbosch. South Africa, Reproduction criteria and meat quality of South African Black (Struthio camelus var. domesticus), Zimbabwean Blue (Struthio camelus australis) and South African Black $\mathrm{x}$ Zimbabwean Blue ostriches, 2006.

41.Lombardi-Boccia G., Lanzi S., Aguzzi A., Aspects of meat quality: Trace elements and $\mathrm{B}$ vitamins in raw and cooked meats. $J$. Food Compost. Anal.;18:39-46, 2005. 